\title{
Maize bushy stunt phytoplasma affects native corn at high elevations in Southeast Mexico
}

\author{
Edel Pérez-López • Chrystel Y. Olivier • Mauricio Luna-Rodríguez • \\ Yesenia Rodríguez • Lourdes G. Iglesias • Alejandro Castro-Luna • \\ Jacel Adame-García • Tim J. Dumonceaux
}

Accepted: 4 February 2016/Published online: 15 February 2016

(C) The Author(s) 2016. This article is published with open access at Springerlink.com

\begin{abstract}
In the 2013-2014 growing season, field surveys were conducted in native corn fields located in high altitude agricultural communities in the 'Sierra Norte de Puebla' in Mexico. Symptoms typical of maize bushy stunt (MBS) disease were observed and DNA extracted from symptomatic native corn plants was used as template to confirm the presence of phytoplasmas.
\end{abstract}

All authors have reviewed the manuscript and approved its submission to the European Journal of Plant Pathology. The manuscript has not been submitted elsewhere.

E. Pérez-López · L. G. Iglesias · A. Castro-Luna Instituto de Biotecnología y Ecología Aplicada (INBIOTECA), Universidad Veracruzana, Avenida de Las Culturas Veracruzanas, Xalapa, Veracruz, Mexico

C. Y. Olivier · T. J. Dumonceaux $(\bowtie)$

Agriculture and Agri-Food Canada, Saskatoon Research Centre, Saskatoon, SK, Canada

e-mail: tim.dumonceaux@agr.gc.ca

M. Luna-Rodríguez

DGI-LATEX, Universidad Veracruzana, Avenida de Las Culturas Veracruzanas, Xalapa, Veracruz, Mexico

Y. Rodríguez

Instituto Tecnológico Superior de Zacapoaxtla, Totoltepec,

Zacapoaxtla, Puebla, Mexico

J. Adame-García

Instituto Tecnológico de Úrsulo Galván, Km. 4.5 Carretera

Cardel-Chachalacas, CP. 91667 Úrsulo Galván, Veracruz, Mexico

T. J. Dumonceaux

Department of Veterinary Microbiology, University of

Saskatchewan, Saskatoon, SK, Canada
Amplification and sequencing of 16S rRNA-encoding sequences and chaperonin 60 universal target (cpn60 UT) sequences followed by in vitro restriction fragment length polymorphism and phylogenetic analyses revealed that the phytoplasma detected belongs to the subgroup 16SrI-B, 'Candidatus Phytoplasma asteris'. Based on 16S rRNA-encoding gene sequence analysis and on a single nucleotide polymorphism within the cpn60 UT sequence, two MBS strains, MBS-Puebla and MBS-Veracruz, were identified. This is the first detection of MBS phytoplasma (MBSP) affecting native corn and the first molecular survey made in corn fields in Mexico to detect and characterize MBSP. We discuss these results in light of the potential evolutionary relationship between corn and MBSP.

Keywords Maize bushy stunt phytoplasma .

Chaperonin $60 \cdot$ Aster yellow $\cdot$ Dalbulus $\cdot$ Mexico

\section{Introduction}

Mexico is the center of origin for corn (Zea mays L.) domestication (Doebley 2004), and is currently one of the five main corn-producing countries in the world (FAO 2012). In Mexico, corn production can be divided into two major categories: commercial production usually practiced by large and medium farmers using modern cultivars and agrochemicals, and traditional production practiced by small and subsistence farmers using no or limited technology (Mejía and Peel 2009). In the Mexican highlands of Puebla, located over $2300 \mathrm{~m}$ 
above sea level (a.s.l), small agricultural communities (fewer than two hectares per farmer), and small 'ejidos' (between two and ten hectares per farmer) use races of native corn that are adapted to the environmental conditions prevalent at high altitudes (Perales and Golicher 2014). Native corn possesses unique genotypes that have been maintained due to selection in local environments and seed interchanges and more than fifty landraces are available to growers in Mexico (Serratos 2009). Diseases affecting these native corn varieties grown by subsistence farmers have an important effect on their livelihoods.

Maize bushy stunt (MBS) disease was first detected in Mexico in 1955 (Maramorosch 1955); however, it was not until 1978 that it was determined to be caused by a phytoplasma (Bascope 1977; Nault 1980; Harrison 1996). Further studies identified the phytoplasma associated with MBS as a 'Candidatus Phytoplasma asteris'related strain belonging to the 16SrI-B subgroup (Lee et al. 1993, 2004). MBS phytoplasma (MBSP) was also detected in Peru (Nault et al. 1979; Hodgetts et al. 2009), Nicaragua (Hruska et al. 1996), Costa Rica (Harrison et al. 1996), Belize (Henríquez et al. 1999), Brazil (Bedendo et al. 1997), and Colombia (Alvarez et al. 2014). In all countries MBSP was identified as a member of the 16SrI-B subgroup but was never reported as affecting a native variety. In commercial corn cultivars, MBS symptoms include chlorotic stripes, reddening and/or yellowing of leaves, stunting, and the adoption of a bushy phenotype (Nault 1980, 1983). It is therefore important to describe the symptoms and understand the geographic distribution of MBS in native corn in order to differentiate it from related diseases and prevent its spread to other crops via insect vectors (Weintraub and Beanland 2006). Further, disease surveillance is crucial to support the farmers who live in remote, high altitude communities in order to provide timely, accurate information on the presence and taxonomy of MBSP in their crops.

Phytoplasma taxonomy is generally based on the comparison of the 16S rRNA-encoding gene sequences (IRPCM 2004). Recently, other ribosomal and protein-encoding genes have been used to improve phytoplasma strain differentiation and/or to develop diagnostic methods (Lee et al. 2010; Davis et al. 2013; Dumonceaux et al. 2014). The Cpn60-encoding gene has been successfully used as a marker for phytoplasma detection and differentiation (Mitrović et al. 2011; Sugawara et al. 2012; Alvarez et al. 2014), and an approximately 550 bp portion of this gene, known as the chaperonin 60 universal target (cpn60UT) (Goh et al. 1996) can be universally accessed and used to differentiate phytoplasmas (Pérez-López et al. 2014; Dumonceaux et al. 2014).

This study is the result of a large survey of native corn-producing communities located in the 'Sierra norte de Puebla' in Mexico, aimed at detecting and identifying phytoplasma associated with MBS in native corn. Corn plants expressing phytoplasma disease-like symptoms were sampled and analyzed using the 16S rRNA gene and cpn60 UT sequences as markers. This study is the first molecular survey of corn plants affected by MBSP in Mexico, identifying two strains, MBS Puebla and MBS Veracruz. The long term relationship between MBSP and corn plants is discussed.

\section{Materials and methods}

Field plant collection and storage Two surveys were conducted during the growing season of 2013-2014 in three agricultural communities in the states of Puebla and Veracruz, Mexico (Table 1). The surveys were conducted during the months of July and November 2014 (4 and 8 months after planting). At four months plants were completely developed but without cobs, and at 8 months the plants showed completely developed cobs. Whole plants of native corn expressing phytoplasma disease-like symptoms along with asymptomatic plants (Table 1) were collected and placed in plastic bags for transportation. Once in the laboratory, plants were stored at $4{ }^{\circ} \mathrm{C}$ until DNA extraction. Plant tissue used to extract DNA from each sample was selected based on symptom expression (Table 2).

DNA extraction For field collected samples and germinated corn plants, DNA was extracted from $0.3 \mathrm{~g}$ of tissue through a modified CTAB method (Murray and Thompson 1980). Briefly, the tissues were immersed in liquid nitrogen for $30 \mathrm{~s}$, macerated with a mortar and pestle in $2.5 \mathrm{ml}$ of extraction buffer (100 mM Tris-base pH 8, $150 \mathrm{mM} \mathrm{NaCl}, 25 \mathrm{mM}$ EDTA, $8 \mathrm{mM}$ polyvinylpyrrolidone, $50 \mathrm{mM}$ cetyltrimethyl ammonium bromide and $0.2 \% \beta$-mercaptoethanol) and incubated for $30 \mathrm{~min}$ at $65{ }^{\circ} \mathrm{C}$. After centrifugation at $14000 \times g$ for $10 \mathrm{~min}$, the supernatants $(\sim 900 \mu \mathrm{l})$ were transferred into clean Eppendorf tubes and $900 \mu \mathrm{l}$ of chloroform: isoamyl alcohol (24:1, v: v) was added. The tubes were then 
Table 1 Geographic location of sampling sites and number of samples collected per site and per symptomatic crop

\begin{tabular}{|c|c|c|c|c|}
\hline State & Community & Coordinates & $\begin{array}{l}\text { Altitude range } \\
\text { (meters a.s.l) }\end{array}$ & $\begin{array}{l}\text { Native corn } \\
\text { samples (n) }\end{array}$ \\
\hline \multirow[t]{2}{*}{ Puebla } & $\begin{array}{l}\text { Ejido Las Trancas, } \\
\text { Zaragoza }\end{array}$ & $\begin{array}{l}19^{\circ} 43^{\prime} 27.8^{\prime \prime} \mathrm{N}, 97^{\circ} 35^{\prime} 21.0^{\prime \prime} \mathrm{W} ; \\
19^{\circ} 43^{\prime} 27^{\prime \prime} \mathrm{N}, 97^{\circ} 35^{\prime} 16.5^{\prime \prime} \mathrm{W} ; 19^{\circ} 43^{\prime} 42.3^{\prime \prime} \mathrm{N}, 97^{\circ} 34^{\prime} 46.4^{\prime \prime} \mathrm{W} ; \\
19^{\circ} 43^{\prime} 39.6^{\prime \prime} \mathrm{N}, 97^{\circ} 34^{\prime} 45.1^{\prime \prime} \mathrm{W} ; 9^{\circ} 43^{\prime} 45.8^{\prime \prime} \mathrm{N}, 97^{\circ} 51^{\prime} 48.5^{\prime \prime} \mathrm{W} ;\end{array}$ & \multirow[t]{2}{*}{2376 to 2406} & \multirow[t]{2}{*}{97} \\
\hline & $\begin{array}{l}\text { Ejido mazapa, } \\
\text { Zacapoaxtla }\end{array}$ & $\begin{array}{l}19^{\circ} 44^{\prime} 07.1^{\prime \prime} \mathrm{N}, 97^{\circ} 35^{\prime} 42.3^{\prime \prime} \mathrm{W} ; 19^{\circ} 44^{\prime} 04.6^{\prime \prime} \mathrm{N}, 97^{\circ} 35^{\prime} 43.6^{\prime \prime} \mathrm{W} ; \\
19^{\circ} 44^{\prime} 10.3^{\prime \prime} \mathrm{N}, 97^{\circ} 35^{\prime} 40.6^{\prime \prime} \mathrm{W} ; 19^{\circ} 44^{\prime} 05.4^{\prime \prime} \mathrm{N}, 97^{\circ} 35^{\prime} 41.3^{\prime \prime} \mathrm{W} ; \\
19^{\circ} 43^{\prime} 40.0^{\prime \prime} \mathrm{N}, 97^{\circ} 35^{\prime} 46.2^{\prime \prime} \mathrm{W}\end{array}$ & & \\
\hline Veracruz & $\begin{array}{l}\text { Las Vigas, Las Vigas } \\
\text { de Ramirez }\end{array}$ & $\begin{array}{l}19^{\circ} 38^{\prime} 16^{\prime \prime} \mathrm{N}, 97^{\circ} 6^{\prime} 110.0^{\prime \prime} \mathrm{W} ; 19^{\circ} 39^{\prime} 0.7^{\prime \prime} \mathrm{N}, 97^{\circ} 4^{\prime} 28.5^{\prime \prime} \mathrm{W} \\
19^{\circ} 39^{\prime} 1.8^{\prime \prime} \mathrm{N}, 97^{\circ} 4^{\prime} 29.2^{\prime \prime} \mathrm{W}\end{array}$ & 2317 to 2382 & 59 \\
\hline
\end{tabular}

vortexed and centrifuged at $14000 \times \mathrm{g}$ for $5 \mathrm{~min}$. The aqueous phases $(\sim 800 \mu \mathrm{l})$ were transferred into clean $1.5 \mathrm{ml}$ microcentrifuge tubes with $500 \mu \mathrm{l}$ of isopropanol to precipitate the DNA and incubated for $1 \mathrm{~h}$ at $-20{ }^{\circ} \mathrm{C}$. After centrifugation at $14000 \mathrm{~g}$ for $5 \mathrm{~min}$ and removal of the supernatant, DNA was washed twice with $70 \%$ ethanol, dried and resuspended in $30 \mu \mathrm{l}$ of sterile water.

PCR amplification and sequencing DNA was diluted $1 / 10$ in $10 \mathrm{mM}$ Tris- $\mathrm{HCl}(\mathrm{pH} 8.5)$, and used as a template for PCR amplification of the 16S rRNA-encoding gene using phytoplasma universal primers P1/Tint (Smart et al.
1996) or R16F2n/R16R2 (Gundersen and Lee 1996), and amplification of the cpn60UT sequence with primers H279p/H280p:D0317/D0318 (1:7 ratio) (Dumonceaux et al. 2014) following the protocol described by authors. All amplifications were performed in $50 \mu \mathrm{l}$ mixtures containing 1X Taq polymerase buffer (Invitrogen, Burlington, Canada), $500 \mathrm{nM}$ dNTP, $400 \mathrm{nM}$ of each primer, $2 \mu \mathrm{l}$ of diluted DNA (about $10 \mathrm{ng}$ ), and $2.5 \mathrm{mM} \mathrm{MgCl}_{2}$. Phytoplasma DNA was revealed by the presence of 1600, 1200 or 604 bp amplicons, depending on the primers and PCR conditions used, when observed in an ethidium bromide-stained $1 \%$ agarose gel using an

Table 2 Results obtained after analysis of all the samples collected in the communities per symptom and tissue used to extract DNA

\begin{tabular}{|c|c|c|c|c|c|c|c|c|}
\hline \multirow[b]{3}{*}{ Acronym } & \multirow[b]{3}{*}{ Description } & \multirow[b]{3}{*}{ Tissue } & \multicolumn{6}{|l|}{$(+/$ total $)$} \\
\hline & & & \multicolumn{2}{|l|}{$16 \mathrm{~S}-23 \mathrm{~S}$} & \multicolumn{2}{|l|}{$16 \mathrm{~S}$} & \multicolumn{2}{|l|}{ cpn60UT } \\
\hline & & & Veracruz & Puebla & Veracruz & Puebla & Veracruz & Puebla \\
\hline MCA & Maize control asymptomatic & Midrib & $0 / 6$ & $0 / 6$ & n.e & n.e & n.e & n.e \\
\hline MLL & Maize little leaves & Midrib & n.o & $1 / 3$ & n.e & $0 / 1$ & n.e & n.e \\
\hline MGR & Maize red stripes & Midrib & $3 / 5$ & $1 / 1$ & $2 / 3$ & $0 / 1$ & $2 / 2$ & n.e \\
\hline MAI & Maize atrophied inflorescence & Inflorescence & $1 / 1$ & $1 / 2$ & $0 / 1$ & $0 / 1$ & n.e & n.e \\
\hline MUC & Maize undeveloped cob & Internal part of the cob & $7 / 15$ & $2 / 10$ & $3 / 7$ & $0 / 2$ & $3 / 3$ & n.e \\
\hline MR & Maize redness & Midrib & $11 / 13$ & $3 / 14$ & $9 / 11$ & $0 / 3$ & $9 / 9$ & n.e \\
\hline MSC & Maize symptomatic cob & $\begin{array}{l}\text { Internal part of the cob } \\
\text { mix with kernels }\end{array}$ & $1 / 6$ & $3 / 26$ & $1 / 1$ & $0 / 3$ & $1 / 1$ & n.e \\
\hline MYL & Maize yellow stripes & Midrib & $5 / 8$ & $8 / 28$ & $3 / 5$ & $2 / 8$ & $3 / 3$ & $2 / 2$ \\
\hline MS & Maize stunt & Midrib & $2 / 9$ & n.o & $2 / 2$ & n.e & $2 / 2$ & n.e \\
\hline MAS & Maize atrophied shoot & Midrib & $2 / 2$ & $4 / 8$ & $0 / 2$ & $1 / 4$ & n.e & $1 / 1$ \\
\hline MRM & Maize red midrib & Midrib & n.o & $1 / 4$ & n.e & $0 / 2$ & n.e & n.e \\
\hline MYLG & Maize yellow border & Midrib & n.o & $1 / 1$ & n.e & $0 / 1$ & n.e & n.e \\
\hline Total & & & $33 / 67$ & $35 / 140$ & $20 / 33$ & $3 / 35$ & $20 / 20$ & $3 / 3$ \\
\hline
\end{tabular}

Refers to the number of plants that were positive with the corresponding set of primers of the total of plants per symptom n.o, not observed, and n.e, not evaluated 
ultraviolet transiluminator set at $365 \mathrm{~nm}$ (AIML 26, Alpha Innotech Corp., San Leandro, CA, USA).

Amplicons were purified using QIAquick ${ }^{\circledR}$ PCR Purification Kit (QIAGEN, Toronto, Canada) and directly sequenced using the amplification primers. The 16S rRNA-encoding genes and cpn60 UT amplified from samples NMBSP-P144 and NMBSP-V41 were ligated into the vector pGEM-T Easy (Promega, Madison, WI USA) following the manufacturer's recommendations, transformed into chemically competent E. coli TOP10 (Invitrogen, ON, Canada), and sequenced using primers T7/SP6.

Phylogeny and RFLP analysis The 16S rRNAencoding gene and cpn60 UT sequences generated in this study were assembled using the Staden package (Bonfield and Whitwham 2010), and compared with reference sequences from GenBank using BLAST (http://www.ncbi.nlm.nih.gov). Phylogenetic analysis was conducted using the Maximum Parsimony method with MEGA v6.0 (Tamura et al. 2013), and bootstrapping 1000 times to estimate stability. Acholeplasma laidlawii strain PG-8 A (U14905) was used as outgroup to root the tree.

RFLP patterns obtained after digesting the 16S rRNA gene amplicons amplified from four of the positive samples analyzed in this study with endonucleases EcoRI, HinfI, BfaI and HhaI (Thermo Scientific, Canada), were compared with the RFLP profile of 'Ca.P. asteris' - related strain previously identified by our group. Reactions were incubated at $37{ }^{\circ} \mathrm{C}$ (Thermo Scientific, ON, Canada), and were observed after electrophoresis using $4 \%$ acrylamide gels (Invitrogen, ON, Canada) stained with GelRed (Invitrogen, ON, Canada).

For confirmation of classification, the purified amplicon of one of the positive samples analyzed in this study was digested in single reactions with $A l u \mathrm{I}, B f a \mathrm{I}$, $B s t \mathrm{UI}$, EcoRI, HaeIII, HhaI, Hinfl, and HpaII, at $37^{\circ} \mathrm{C}$, and MseI and Tsp509I at $68^{\circ} \mathrm{C}$ (Thermo Scientific, ON, Canada). After digestion, the samples were observed after electrophoresis using $4 \%$ UltraPure TMAgarose 1000 gel (Invitrogen, ON, Canada), and staining with ethidium bromide.

cpn60UT single nucleotide polymorphism The consensus of the two different cpn60 UT sequences obtained in this study was aligned with twenty publically available Cpn60-encoding gene sequences from 'Ca.P. asteris' related strains using ClustalW (Thompson et al. 1994), and trimmed using the Staden package (Bonfield and Whitwham 2010) to the 552 bp cpn60 universal target (Dumonceaux et al. 2014). The single nucleotide polymorphisms (SNP) present were noted manually.

\section{Results}

Symptoms associated with phytoplasma infection During the first survey in July 2014, native corn plants expressing symptoms of small leaves, reddish leaves and/or leaves with red midribs, leaves with yellow or chlorotic stripes, stunting, atrophied inflorescence, and/or atrophied shoots were observed (Fig. 1). During the second survey, in November 2014, plants with undeveloped cobs and cobs expressing phytoplasma-disease like symptoms such as partial cob filling, small malformed kernels, and high amount of silk or small cobs were observed (Fig. 1). The ratio of symptomatic/total plants collected per symptom as well as the range of symptoms detected differed between the Puebla and Veracruz collection sites (Table 2).

PCR amplification A 16S-23S rRNA fragment amplified with P1/Tint was obtained with 33 samples collected in Veracruz and 35 samples collected in Puebla. The expected band of $1.2 \mathrm{~kb}$ was observed with twenty samples collected in Veracruz, and three samples collected in Puebla. To confirm the results, the $10 \%$ of the symptomatic plants that were negative with primers $\mathrm{P} 1 /$ Tint were also negative with primers R16F2n/R16R2. Amplicons corresponding to the cpn60 UT (552 bp) were observed for the 23 samples that were positive with primers R16F2n/R16R2. No phytoplasma DNA was detected from asymptomatic plants.

Phytoplasma identification The 16S rRNA and the cpn60 UT sequences of the 20 positive samples collected in Veracruz, and one sample collected in Puebla were $100 \%$ identical, while the other two samples collected in Puebla shared only $99 \%$ nucleotide identity with the others. All 23 sequences shared $99 \%$ identity based on the 16S rRNA-encoding sequence with the strain MBS Colombia (MBS-Col) (Genbank accession no. HQ530152), and the strain MBS from Mexico (MBSMex) (GenBank accession no. AY265208). The cpn60 UT sequences of the 20 positive samples collected in Veracruz and one of the positive samples collected in Puebla were $100 \%$ identical to the strain MBS-Col 


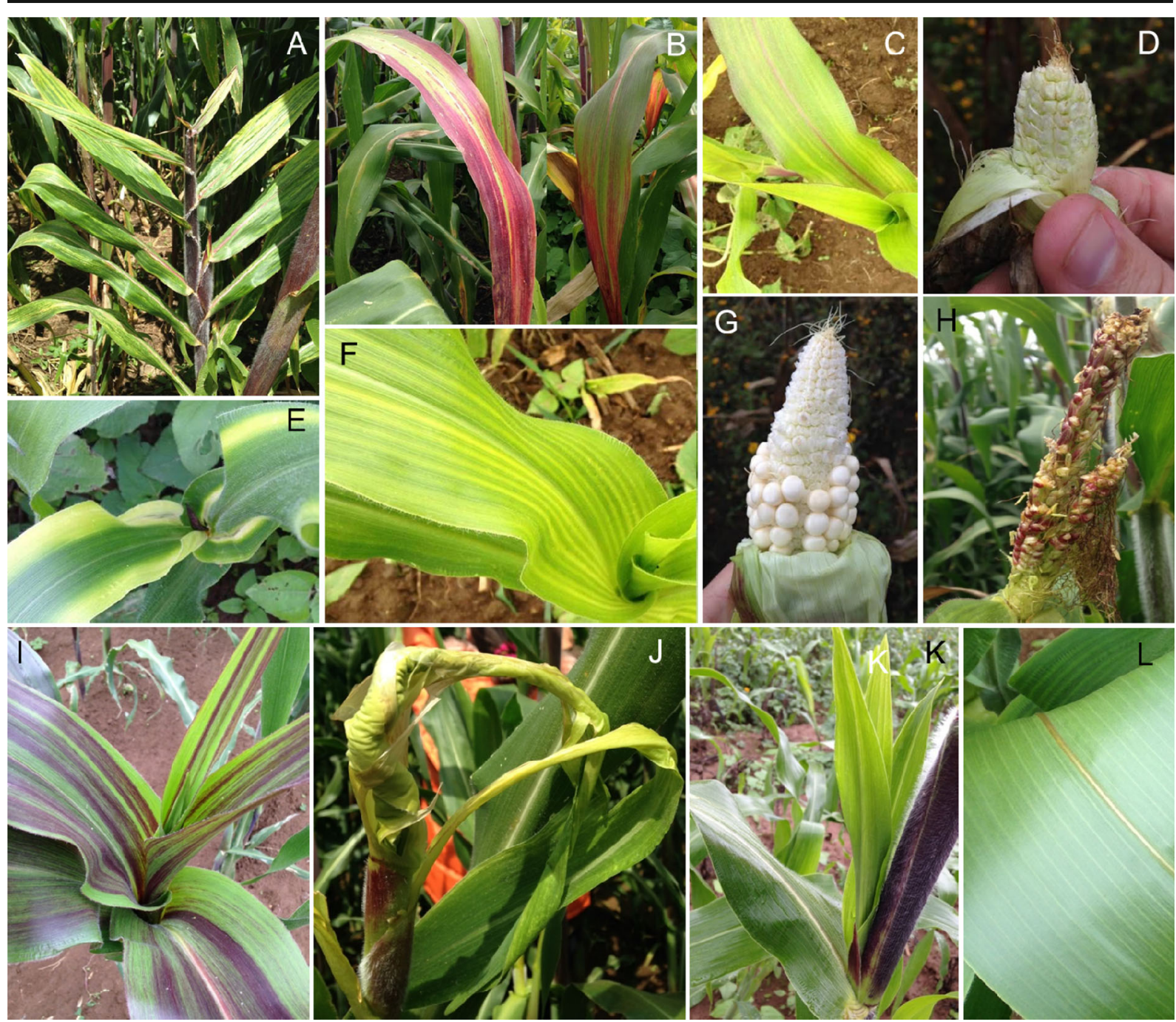

Fig. 1 Symptoms related with phytoplasmas detected at the high elevation communities in different crops. Maize stunt symptom (a); maize redness (b); maize red midrib (c); maize undeveloped cob (d); maize yellow border (e); maize

(GenBank accession no. AB599712), while the remaining two samples were only $99 \%$ identical to the strain MBS-Col based on cpn60 UT sequences.

The cpn60 UT sequences were also deposited into GenBank for strain MBS-Pueb (GenBank accession no. KT444672) and MBS-Ver (GenBank accession no. KT444673). The phylogenetic tree obtained by Maximum Parsimony analysis of the 16S rRNA and cpn60 UT sequences of MBS-Pueb and MBS-Ver showed that the phytoplasmas detected branched with the 'Ca.P. asteris' - related strains from subgroup 16SrI$\mathrm{B}$ and is consistent with the nucleotide similarities observed (Fig. 2). yellow lines (f); maize symptomatic cob (g); maize atrophied inflorescence (h); maize red stripes (i); maize atrophied shoot (j); maize little leaves (k); maize asymptomatic control (l)

RFLP analysis of PCR product primed by R16F2n/ R16R2 with EcoRI, Hinfl, BfaI and HhaI indicated that samples MBS-P144, MBS-P167, MBS-V41, and MBSV44 were identical to each other (Not shown). All reference strains showed the same restriction profile with EcoRI, as expected (Not shown), and digestion with $H h a$ I differentiated the MBS samples from the strain MP reported as a closely related member of 16SrI-F subgroup (Pérez-López et al. 2013). The RFLP profiles of the R16F2n/R16R2- primed amplicon from MBS-P144 with nine of seventeen endonucleases used in the phytoplasma classification scheme and the restriction enzyme $T s p 509$ I were identical to the profile 


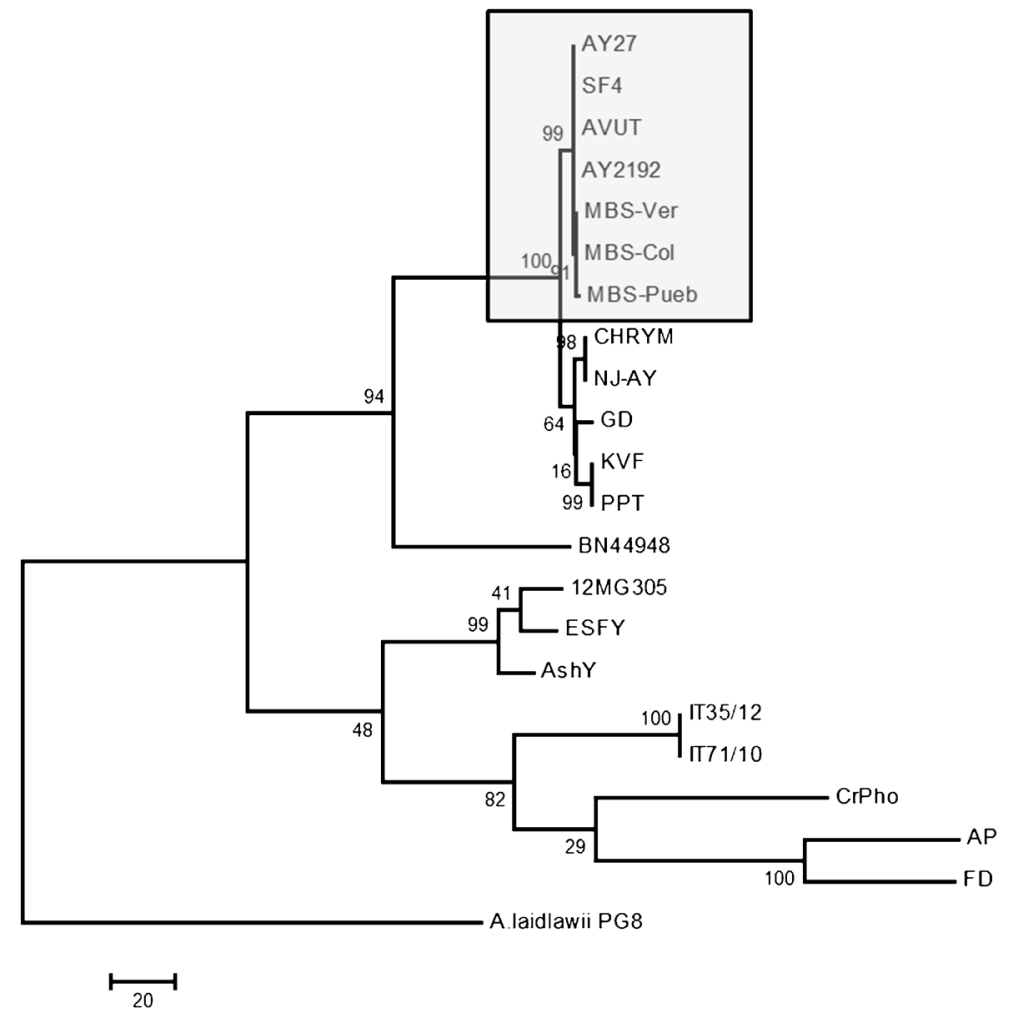

Fig. 2 Evolutionary analysis conducted through a Maximum parsimony phylogenetic tree among the isolates detected in this study and reference sequences from GenBank. Phylogenetic relationship inferred from analysis of cpn60UT sequences (b). GenBank accession numbers of the strains identified in this study are given in the main text. Strains inside 16SrI-B subgroup are grouped into the grey box. Bar, 20 nucleotides substitution.

expected for a member of the subgroup 16SrI-B (Not shown) (Wei et al. 2007).

Diversity of MBSP based on cpn60UT sequences SNP analysis identified differences among the cpn60 UT sequences obtained in this study and the twenty 'Ca.P. asteris'- related strains used as reference. The cpn60 UT amplified from strains MBS-Pueb and MBSVer showed a differential SNP pattern. The SNP based on cpn60 UT confirmed the detection of two different strains between the symptomatic native corn plants collected in this study (Table 3).

\section{Discussion}

Our work was part of a large survey of native cornproducing communities located in the 'Sierra norte de
GenBank accessions numbers: AP (KJ939977), ESFY (KJ940007), BN44948 (KJ940008), 12MG305 (KJ940000), IT71/10 (KF383983), IT35/12 (KF383982), AshY (KJ939978), FD (KJ939992), CrPho (KJ939989), AY-27 (AB599688), CHRYM (AB599692), GD (AB599694), KVF (AB599695), PPT (AB599704), ACLR-AY (AB599699), AVUT (AB599686), MBS-Col (AB599712), SF4 (KJ940016)

Puebla' in Mexico, aiming at detecting and identifying phytoplasma in native corn. Symptomatology and molecular tools revealed the presence of two strains of phytoplasma in native corn. We observed a high number of false positives detected with primers $\mathrm{P} 1 /$ Tint. These primers have been used many times to detect phytoplasmas with good results (Dumonceaux et al. 2014; Torres-Moreno et al. 2013); however nonspecific amplification has previously been a problem with universal primers developed to detect bacteria (Weisburg et al. 1991). For this reason, only the results obtained with the 16S rRNA-encoding gene (R16F2n/ R16R2) and cpn60 UT sequences will be discussed.

Phytoplasma DNA was detected in leaves, stem and shoots, and also in the cobs of the symptomatic corn plants collected. The detection of phytoplasma from symptomatic cobs is not surprising. Many other authors have reported the detection of phytoplasma in plant 
Table 3 Single nucleotide polymorphisms in the cpn60 UT sequences of MBS Puebla, and MBS Veracruz compared with ten of the twenty 'Candidatus Phytoplasma asteris'-related strains used on the analysis

Single nucleotide polymorphism in cpn60UT

\begin{tabular}{|c|c|c|c|c|c|c|c|c|c|c|c|}
\hline Strain & GenBank $^{\S}$ & 6 & 36 & 111 & $125^{*}$ & 146 & 172 & 234 & 465 & $481^{*}$ & 483 \\
\hline MBS-Pue $^{a}$ & KT444672 & $\mathrm{T}$ & G & $\mathrm{C}$ & $\mathrm{T}$ & G & G & G & A & $\mathrm{T}$ & $\mathrm{T}$ \\
\hline MBS-Ver ${ }^{\mathrm{b}}$ & KT444673 & $\mathrm{T}$ & G & $\mathrm{C}$ & $\mathrm{T}$ & G & G & G & A & G & $\mathrm{T}$ \\
\hline MBS-Col $^{b}$ & AB599712 & . & . & . & . & . & . & . & . & G & \\
\hline $\mathrm{AY}-\mathrm{COL}^{\mathrm{c}}$ & KJ939994 & $\mathrm{C}$ & $\mathrm{T}$ & . & $\mathrm{C}$ & . & $\mathrm{T}$ & $\mathrm{T}$ & G & $\mathrm{T}$ & A \\
\hline AVUT $^{\mathrm{d}}$ & AB599686 & . & $\mathrm{T}$ & . & $\mathrm{C}$ & . & $\mathrm{T}$ & . & . & $\mathrm{G}$ & \\
\hline $\mathrm{A}-\mathrm{AY} \mathrm{Y}^{\mathrm{e}}$ & AB599699 & . & $\mathrm{T}$ & . & $\mathrm{C}$ & . & $\mathrm{T}$ & $\mathrm{T}$ & G & $\mathrm{T}$ & A \\
\hline AY $2192^{\mathrm{f}}$ & AB599687 & . & . & . & $\mathrm{C}$ & . & . & . & . & $\mathrm{G}$ & . \\
\hline PopD ${ }^{\mathrm{g}}$ & AB599710 & . & . & . & $\mathrm{C}$ & . & . & . & G & $\mathrm{T}$ & A \\
\hline CanPla- $2^{\mathrm{h}}$ & KJ939984 & . & $\mathrm{T}$ & A & $\mathrm{C}$ & A & $\mathrm{T}$ & $\mathrm{T}$ & G & G & A \\
\hline $\mathrm{GD}^{\mathrm{i}}$ & AB599694 & . & $\mathrm{T}$ & & $\mathrm{C}$ & $\mathrm{T}$ & $\mathrm{T}$ & $\mathrm{T}$ & G & G & $\mathrm{A}$ \\
\hline
\end{tabular}

Superscript letters over the strains grouped based on the SNP in the cpn60 UT sequence

${ }^{\S}$ For strains MBS-Pue, MBS-Ver, AY-COL, SF1, and CanPla-2, the accession number is cpn60 UT. For the rest of the strains the accession number refers to the Cpn60-encoding gene

* Key position to differentiating strains MBS-Pue, and MBS-Ver

organs related to reproduction (Nipah et al. 2007; Olivier et al. 2010). Results of $16 \mathrm{~S}$ rRNA PCR tests showed that the incidence of phytoplasma in native corn was higher in Veracruz (20 positive out of 33 tested) than in Puebla (3 positive out of 35). We observed better management in fields located in Puebla compared to Veracruz with a lower amount of weeds in corn fields (not shown). This suggests that studies of the role of weeds as a reservoir of phytoplasmas for native corn varieties may be important. Although other hosts are certainly possible, one of the most important and prevalent weeds in Veracruz and Puebla are plants from the genus Amaranthus spp.

Samples that tested positive with the $16 \mathrm{~S}$ primers also tested positive with the cpn60 UT primers. The use of protein-encoding genes as part of the scheme of identification and classification of phytoplasmas has been suggested (Davis et al. 2013). The groEL gene has been used to differentiate 'Ca.P. asteris'- related strains (Mitrović et al. 2011; Alvarez et al. 2013), and as target to develop diagnostic methods (Sugawara et al. 2012). In our study, 16S and cpn60 UT sequence analysis resulted in the identification of four consensus sequences representing two strains, MBS-Puebla and MBS-Veracruz, both belonging to the subgroup 16SrI$B$. The $16 \mathrm{~S}$ sequences were nearly identical and were differentiated based on their sampling location. The cpn60 UT sequences of MBS-Puebla and MBSVeracruz belonged to two strains, in agreement with 16S PCR identification. This provides further evidence that the cpn60 UT sequence can be used as a diagnostic target, and as an additional marker to differentiate phytoplasma strains.

Our results confirmed the association of two phytoplasma strains, named MBS-Puebla and MBS-Veracruz, belonging to 'Ca.P. asteris' species, and members of the subgroup 16SrI-B, with native corn in high elevation communities of Puebla and Veracruz in southeast Mexico. To our knowledge, this is the first molecular confirmation of the presence of MBSP, and the first report of the symptomatology of MBSP-infected native corn in Mexico.

The idea of an evolutionary relationship between MBSP and corn plants came from the study of the genus Dalbulus and its relationship with corn plants (Nault and Delong 1980). Southern Mexico has been considered the center of diversity and speciation of the genus Dalbulus, a genus that includes the reported MBSPvectors, and is also the center of evolution and domestication of maize from teosinte (Zea mays ssp. Parviglumis) (Nault and Delong 1980; Doebley 2004). The 'corn leafhopper' (Dalbulus maidis), and the 'Mexican corn leafhopper' (Dalbulus elimatus), showed a natural preference for corn as a food source and a 
reproductive host, and a high rate of tolerance to the MBSP infection and efficient subsequent transmission (Nault and Delong 1980; Nault 1980, 1983). The relationship among corn, Dalbulus leafhoppers, and MBSP has been maintained since the detection of the disease, and reported throughout the Americas, suggesting a biological differentiation and specialization. Although more information and studies are need, our results have added evidence of the probable specialization and evolutionary relationship among the plant, vector, and the pathogenic prokaryote.

Studies of the presence of Dalbulus spp. and other insect vectors in native corn, the incidence and impact of MBS in native corn, and the implications of the disease for the farmers in the highland communities of Mexico are ongoing. With this research we have established a baseline for efficient management strategies that aim to increase the productivity of farmers producing these important corn varieties.

Acknowledgments We thank the farmers from Mazapa and Las Trancas for the support and cooperation. We also thank Christine Hammond and Dana Nordin for their support in lab work, and Jennifer Town for critical review of the manuscript. Finally, we thank Dr. Robert E. Davis for his helpful advice. This work was supported by the Genomic Research and Development Initiative for the shared priority project on quarantine and invasive species. E. Pérez-López thanks CONACYT for PhD scholarship (CVU: 517835) and AAFC-Saskatoon Research and Development Centre for the laboratory space and warm welcome.

Open Access This article is distributed under the terms of the Creative Commons Attribution 4.0 International License (http:// creativecommons.org/licenses/by/4.0/), which permits unrestricted use, distribution, and reproduction in any medium, provided you give appropriate credit to the original author(s) and the source, provide a link to the Creative Commons license, and indicate if changes were made.

\section{References}

Alvarez, E., Mejía, J. F., Contaldo, N., Paltrinieri, S., Duduk, B., \& Bertaccini, A. (2014). 'Candidatus Phytoplasma asteris' strains associated with oil palm lethal wilt in Colombia. Plant Disease, 98, 311-318.

Bascope, B. (1977). Agente causal de la llamada 'raza mesa central" del achaparramiento del maiz (55 pp). Escuela Nacional de Agricultura, Chapingo, Mexico: Maestro en Ciencias Thesis.

Bedendo, I. P., Davis, R. E., \& Dally, E. L. (1997). Molecular evidence for the presence of maize bushy stunt phytoplasma in corn in Brazil. Plant Disease, 81, 957.
Bonfield, J. K., \& Whitwham, A. (2010). Gap5 - editing the billion fragment sequence assembly. Bioinformatics, 26, 1699-1703.

Davis, R. E., Zhao, Y., Dally, E. L., Lee, I.-M., Jomantiene, R., \& Douglas, S. M. (2013). 'Candidatus Phytoplasma pruni', a novel taxon associated with X-disease of stone fruits, Prunus spp.: multilocus characterization based on 16SrRNA, secY, and ribosomal protein genes. International Journal of Systematic and Evolutionary Microbiology, 63, 766-776.

Doebley, J. (2004). The genetics of maize evolution. Annual Review of Genetic, 38, 37-59.

Dumonceaux, T. J., Green, M., Hammond, C., Perez, E., \& Olivier, C. (2014). Molecular diagnostic tools for detection and differentiation of phytoplasmas based on chaperonin- 60 reveal differences in host plant infection patterns. PloS One, 9, e116039.

FAO. 2012. FAOSTAT, production. Cited May, 8, 2015. http:// faostat.fao.org/site/567/DesktopDefault.aspx?PageID= 567 \#ancor.

Goh, S. H., Potter, S., Wood, J. O., Hemmingsen, S. M., Reynolds, R. P., \& Chow, A. (1996). HSP60 gene sequences as universal targets for microbial species identification: studies with coagulase-negative staphylococci. Journal of Clinical Microbiology, 34, 818-823.

Gundersen, D. E., \& Lee, I.-M. (1996). Ultrasensitive detection of phytoplasma by nested-PCR assays using two universal primer pairs. Phytopathologia Mediterranea, 35, 114-151.

Harrison, N. A., Richardson, P. A., Tsai, J. H., Ebbert, M. A., \& Kramer, J. B. (1996). PCR assay for detection of the phytoplasma associated with maize bushy stunt disease. Plant Disease, 80, 263-269.

Henríquez, N. P., Kenyon, L., \& Quiroz, L. (1999). Corn stunt complex Mollicutes in Belize. Plant Disease, 83, 77.

Hodgetts, J., Chuquillangui, C., Muller, G., Arocha, Y., Gamarra, D., Pinillos, O., Velit, E., Lozada, P., Boa, E., Boonham, N., Mumford, R., Barker, I., \& Dickinson, M. (2009). Surveys reveal the occurrence of phytoplasmas in plants at different geographical locations in Peru. Annal of Applied Biology, $155,15-27$.

Hruska, A. J., Gladstone, S. H., \& Obando, R. (1996). Epidemic roller coaster: maize stunt disease in Nicaragua (pp. 248252). Winter: American Entomologist.

IRPCM (2004). 'Candidatus Phytoplasma', a taxon for the wallless, non-helical prokaryotes that colonize plant phloem and insects. International Journal of Systematic and Evolutionary Microbiology, 54, 1243-1255.

Lee, I.-M., Hammond, R. W., Davis, R. E., \& Gundersen, D. E. (1993). Universal amplification and analysis of pathogen $16 \mathrm{~S}$ rDNA for classification and identification of mycoplasmalike organisms. Phytopathology, 83, 834-842.

Lee, I.-M., Gundersen-Rindal, D. E., Davis, R. E., Bottner, K. D., Marcone, C., \& Seemüller, E. (2004). 'Candidatus Phytoplasma asteris', a novel phytoplasma taxon associated with aster yellows and related diseases. International Journal of Systematic and Evolutionary Microbiology, 54, 1037-1048.

Lee, I.-M., Bottner-Parker, K. D., Zhao, Y., Davis, R. E., \& Harrison, N. A. (2010). Phylogenetic analysis and delineation of phytoplasmas based on secY gene sequences. International Journal of Systematic and Evolutionary Microbiology, 60, 2887-2897. 
Maramorosch, K. (1955). The occurrence of two distinct types of corn stunt in Mexico. Plant Disease Report, 39, 896-898.

Mejía, M., \& Peel, D.S. (2009). White and yellow Corn Production in Mexico: food versus feed, analysis and comments, letter no. 25 , livestock marketing information center, Denver, CO, June.

Mitrović, J., Kakizawa, S., Duduk, B., Oshima, K., Namba, S., \& Bertaccini, A. (2011). The groEL gene as an additional marker for finer differentiation of 'Candidatus Phytoplasma asteris'related strains. Annals of Applied Biology, 159, 41-48.

Murray, M. G., \& Thompson, W. F. (1980). Rapid isolation of high molecular weight plant DNA. Nucleic Acids Research, 239, 487-491.

Nault, L. R. (1980). Maize bushy stunt and corn stunt: a comparison of disease symptoms, pathogen host ranges, and vectors. Phytopathology, 70, 659-662.

Nault, L. R. (1983). Origins in Mesoamerica of maize viruses and mycoplasmas and their leafhopper vectors. In R. T. Plumb, \& J. M. Thresh (Eds.), Plant virus epidemiology: the spread and control of insect-borne viruses (pp. 259-266). Oxford, England: Blackwell.

Nault, L. R., \& Delong, D. M. (1980). Evidence for Co-evolution of leafhoppers in the genus Dalbulus (Cicadellidae: Homoptera) with maize and its ancestors. Annals of the Entomological Society of America, 73, 349-353.

Nault, L. R., Gordon, D. T., Gingery, R. E., Bradfute, O. E., \& Loayza, J. C. (1979). Identification of maize viruses and mollicutes and their potential insect vectors in Peru. Phytopathology, 69, 824-828.

Nipah, J. O., Jones, P., Hodgetts, J., \& Dickinson, M. (2007). Detection of phytoplasma DNA in embryos from coconut palms in Ghana, and kernels from maize in Peru. Bulletin of Insectology, 60, 385-386.

Olivier, C. Y., Galka, B., \& Séguin-Swartz, B. (2010). Detection of aster yellows phytoplasma DNA in seed and seedlings of canola (Brassica napus and B. rapa) and AY strain identification. Canadian Journal of Plant Pathology, 32, 298-305.

Perales, H., \& Golicher, D. (2014). Mapping the diversity of maize races in Mexico. PloS one, 9(12), e114657.

Pérez-López, E., Hernández-Rodríguez, L., Pantoja, M. L., \& Zaldívar, M. R. H. (2013). First report of a 'Candidatus
Phytoplasma asteris' isolate affecting macadamia nut trees in Cuba. New Disease Reports, 28, 1.

Pérez-López, E., Dumonceaux, T. J., Olivier, C. Y., \& LunaRodríguez, M. (2014). Identification of 'Candidatus phytoplasma phoenicium' in periwinkle from Cuba. Revista Mexexicana de Fitopatología, 32, S47.

Serratos, J. A. H. (2009). El origen y la diversidad del maiz en el continente americano, Lara, A., and Navarro, C., eds. Mexico, Mexico: Greenpeace.

Smart, C. D., Schneider, B., Blomquist, C. L., Guerra, L. J., Harrison, N. A., Ahrens, U., Lorenz, K. H., Seemüller, E., \& Kirkpatrick, B. C. (1996). Phytoplasma-specific PCR primers based on sequences of the 16S-23S rRNA spacer region. Applied and Environmental Microbiology, 62, 2988-2993.

Sugawara, K., Himeno, M., Keima, T., Kitazawa, Y., Maejima, K., Oshima, K., \& Namba, S. (2012). Rapid and reliable detection of phytoplasma by loop-mediated isothermal amplification targeting a housekeeping gene. Journal of General Plant Pathology, 78, 389-397.

Tamura, K., Stecher, G., Peterson, D., Filipski, A., \& Kumar, S. (2013). MEGA6: molecular evolutionary genetics analysis version 6.0. Molecular Biology and Evolution, 30, 2725-2729.

Thompson, J. D., Higgins, D. G., \& Gibson, T. J. (1994). CLUSTAL W: improving the sensitivity of progressive multiple sequence alignment through sequence weighting, position-specific gap penalties and weight matrix choice. Nucleic Acids Research, 22, 4673-4680.

Torres-Moreno, R., Moya-Raygoza, G., \& Pérez-López, E. (2013). Absence of corn stunt spiroplasma and maize bushy stunt phytoplasma in leahoppers (Hemiptera: Cicadellidae) that inhabit edge grasses throughout winter in Jalisco, Mexico. Florida Entomologist, 98, 967-969.

Wei, W., Davis, R. E., Lee, I.-M., \& Zhao, Y. (2007). Computersimulated RFLP analysis of 16S rRNA genes: identification of ten new phytoplasma groups. International Journal of Systematic and Evolutionary Microbiology, 57, 1855-1867.

Weintraub, P. G., \& Beanland, L. (2006). Insect vectors of phytoplasmas. Annual Review of Entomology, 51, 91-111.

Weisburg, W. G., Barns, S. M., Pelletier, D. A., \& Lane, D. J. (1991). 16S ribosomal DNA amplification for phylogenetic study. Journal of Bacteriology, 173, 697-703. 